\title{
A Case Study on Partial Replacement of Cement by Saw Dust Ash in Concrete
}

\author{
Ratod Vinod Kumar', M. Shiva Rama Krishna ${ }^{2}$. \\ ${ }^{1}$ Assistant Professor, Mallareddy Institute of Technology \& Science, Maisammaguda, Dulapally, Rangareddy, TS, India, 500100 \\ ${ }^{2}$ Student of Mallareddy Institute of Technology \&Science, Maisammaguda, Dulapally, Rangareddy, TS, India, 500100
}

\begin{abstract}
The sustainable utilization and minimization of industrial and domestic wastes provides secondary raw materials that lead to sustainable technologies. This research proposal looked into the viability of the use of saw dust ash as a partial cement replacement material and compared the fresh and hardened concrete properties of the saw dust ash concrete and Portland cement concrete. The methodology of the study was mainly laboratory testing of the materials. The scope of the research covered the potential of using saw dust ash in India as a cement replacement material. From the research, it was found out that saw dust ash concrete compared well with Portland cement concrete up to $12 \%$ cement replacement. Further replacement, however, would be detrimental to the strength of the concrete. The saw dust ash concrete was also found to be cheaper and friendlier to the environment than Portland cement concrete in proportion to the percentage of cement replaced. The main recommendation therefore was to replace cement with $12 \%$ saw dust ash as this particular proportion of replacement would enable cost savings, reduction of environmental pollution and achievement of normal strength concrete as well. The findings of this research call for the safe use and disposal of saw dust and its ash and should also ignite an interest in the cement industry to produce cement that is friendlier to the environment - "green cement"
\end{abstract}

Keywords: introduction, literature review. Methodology, results and discursion, recommendations, conclusion

\section{Introduction}

Globally, the only substance people use the most in massive volume more than cement is water. This is because cement is an excellent building material, being inexpensive, pourable and also hardens as rock overtime. The only problem is that cement is dirty as it pollutes the environment. This is because the main constituent of cement is limestone which is the main contributor to the pollution caused by the manufacture and use of cement.

\section{Purpose of the Study}

The objectives of the research are:

1) To analyze the properties of the saw dust ash concrete as compared to Portland cement concrete.

2) To test some of the properties of saw dust ash.

3) To do a cost comparison of the saw dust ash concrete with Portland cement concrete.

4) To approximate the reduction of carbon emissions that would result from the use of saw dust ash as a partial replacement to cement.

The research shall seek to find out the mineral composition of saw dust ash and further test it as a cement replacement alternative. The research shall also seek to find out the optimum mix design for the use of saw dust ash as a partial replacement of cement.

This study shall positively contribute to future advances in green cement production in which the use of limestone will have been reduced or eliminated altogether.

\section{Literature Review}

Mohammad Iqbal Malik is presented a paper on Concrete industry is one of the largest consumers of natural resources due to which sustainability of concrete industry is under threat. The environmental and economic concern is the biggest challenge concrete industry is facing. In their paper, the issues of environmental and economic concern were addressed by the use of saw dust ash as partial replacement of cement in concrete. Cement was replaced by Saw Dust Ash as $5 \%, 10 \%, 15 \%$ and $20 \%$ by weight for M-25 mix. The concrete specimens were tested for compressive strength, durability (water absorption) and density at 28 days of age and the results obtained were compared with those of normal concrete. The results concluded the permissibility of using Saw Dust Ash as partial replacement of cement up to $10 \%$ by weight for particle size of range 90 micron.

C.Marthong is published a paper on The possibility of using Sawdust Ash (SDA) as a construction material was experimentally investigated. Saw dust was burnt and the ash sieved using a 90 micron sieve. Three grades of ordinary Portland cement (OPC) namely; 33, 43 and 53 as classified by Bureau of Indian Standard (BIS) are commonly used in construction industry. A comparative study on effects of concrete properties when OPC of varying grades was partially replaced by SDA is discussed in this paper. Percentage replacement of OPC with SDA was 0, 10, 20, 30 and $40 \%$ respectively. Experimental investigations are carried out on mortar cubes, concrete cubes and beams specimens. The mix was designed for target cube strength of $30 \mathrm{MPa}$ at 28 days with water-cement ratio of 0.38 . The compressive strength, water absorption, shrinkage and durability of concrete were mainly studied. Test results shows that, inclusion of SDA cause little expansion due to low calcium content. Early strength development was observed to be about $50-60 \%$ of their 28 days strength. The 


\section{International Journal of Science and Research (IJSR) \\ ISSN (Online): 2319-7064 \\ Index Copernicus Value (2013): 6.14 | Impact Factor (2015): 6.391}

study suggests the use of SDA as partial replacement of cement up to a maximum of $10 \%$ by volume in all grades of cement.

\section{Methodology}

The Methodology section covers the means by which the objectives of the research were attained. It covers the determination of different proportions of materials for the mix design, the preparation and tests on aggregates, the preparation and tests on saw dust ash and the tests on properties of the fresh and hardened concrete.

\section{M25 Mix Design: STIPULATIONS \\ PROPORTIONING}

(a) Grade designation : M25

(b) Type of cement : PPC 53 Grade conforming to IS 8112

(c) Maximum nominal size of aggregate : $20 \mathrm{~mm}$

(d) Minimum cement content : $360 \mathrm{~kg} / \mathrm{m}^{3}$

(e) Maximum water-cement ratio : 0.45

(f) Workability : $50 \mathrm{~mm}$ (slump)

(g) Exposure condition : moderate

(h) Method of concrete placing : manually placed

(i) Degree of supervision : good

(j) Aggregate type : crushed angular aggregate

(k) Maximum cement content : $500 \mathrm{~kg} / \mathrm{m}^{3}$

(l) Chemical admixture type : Not recommended

\section{TEST DATA FOR MATERIALS}

a) Cement used : PPC 53 grade conforming to IS 8112

b) Specific gravity of cement : 3.15

c) Chemical admixture : Not recommended

d) Specific gravity of

Coarse aggregate $: 2.75$

Fine aggregate $: 2.63$

e) Water absorption :

coarse aggregate : $0.5 \%$

fine aggregate : $1.0 \%$

\section{STEP- 1: Determinations of target mean strength:}

$\mathrm{f}^{\prime} \mathrm{ck}=\mathrm{fck}+\mathrm{k} . \mathrm{s}$

Where, $\mathrm{f}^{\prime} \mathrm{ck}=$ target average compressive strength at 28 days,

$\mathrm{fck}=$ characteristic compressive strength at 28 days, and

$\mathrm{S}=$ standard deviation

From IS 456:2000 Table 1, standard deviation, $\mathrm{S}=4 \mathrm{~N} / \mathrm{mm} 2$

Therefore, target strength $=25+1.65 \times 4$

$=31.6 \mathrm{~N} / \mathrm{mm} 2$

STEP 2: Selection of water-cement ratio:

From the Table 5 of IS 456:2000 maximum water-cement ratio $=0.45$

Based on experience, adopt water-cement ratio as 0.45 , hence ok.

\section{STEP 3: Selection of water content:}

From code book maximum water content $=186 \mathrm{~kg}$ (for 25 $\mathrm{mm}$ to $50 \mathrm{~mm}$ slump) for $20 \mathrm{~mm}$ aggregate

Estimated water content for $50 \mathrm{~mm}$ slump $=186 \mathrm{~kg} / \mathrm{m}^{3}$

Step-4: Calculation of cement::

Water-cement ratio Cement content $=0.45$

$=186 / 0.45=415 \mathrm{~kg} / \mathrm{m}^{3}$
From Table5 of IS 456, minimum cement content for 'moderate' exposure condition $=360 \mathrm{~kg} / \mathrm{m}^{3}$

$415 \mathrm{~kg} / \mathrm{m}^{3}>360 \mathrm{~kg} / \mathrm{m}^{3}$, hence O.K

Step-5: PROPORTION OF VOLUME OF COARSE AGGREGATE AND FINE AGGREGATE CONTENT:

From volume of coarse aggregate corresponding to $20 \mathrm{~mm}$ size aggregate and fine aggregate (Zone I) for water-cement ratio of $0.50=0.60 \mathrm{In}$ the present case $\mathrm{w} / \mathrm{c}=0.45$. The volume of coarse aggregate is required to be increased to decrease the fine aggregate content. As w/c ratio is lower by 0.10 , increase the coarse aggregate volume by 0.02 ( at the rate of $-/+0.01$ for every +/- 0.05 change in water cement FOR ratio). Therefore corrected volume of coarse aggregate for w/c of $0.40=0.62$

For pumpable concrete these values should be reduced by 10 percent Therefore volume of coarse aggregate $=0.62 \mathrm{x}$ $0.9=0.56$ Volume of fine aggregate content $=1-0.56=$ 0.44

\section{STEP 6: Mix calculations:}

The mix calculations per unit volume of concrete shall be as follows:

a) Volume of Concrete $=1 \mathrm{~m}^{3}$

b) Volume of Cement $=\frac{\text { mass of cement }}{\text { Specific gravity of cement }} \times \frac{1}{1000}$

$=\frac{415}{3.15} \times \frac{1}{1000}$

$=0.131 \mathrm{~kg} / \mathrm{m}^{3}$

$$
\begin{aligned}
& =\frac{\text { Mass of Water }}{\text { Specific gravity of Water }} \times \frac{1}{1000} \\
& =186 \div 1 \times 1 \div 1000 \\
& =\quad 0.186 \mathrm{~kg} / \mathrm{m}^{3}
\end{aligned}
$$

d) Volume of all in Aggregate $(E)=(a-(b+c))$ $=(1-(0.131+0.186))$ $=0.683 \mathrm{~kg} / \mathrm{m}^{3}$

e) Mass of Coarse Aggregate (C.A)

$=\mathrm{E} \times$ Volume of C.A $\times$ specific gravity of C.A $\times 1000$

$=0.683 \times 0.56 \times 2.63 \times 1000$

$=1180 \mathrm{~kg} / \mathrm{m}^{3}$

f) Mass of Fine Aggregate (F.A)

$=\mathrm{E} \times$ Volume of F.A $\times$ specific gravity of F.A $\times 1000$

$=0.683 \times 0.44 \times 2.75 \times 1000$

$=584.10 \mathrm{~kg} / \mathrm{m}^{3}$

Mix proportions for trial:

Cement $=415 \mathrm{Kg} / \mathrm{m}^{3}$

Water $=186 \mathrm{~kg} / \mathrm{m}$

Fine Aggregate $=584.10 \mathrm{~kg} / \mathrm{m}^{3}$

Coarse Aggregate $=1180 \mathrm{kgs} / \mathrm{m}^{3}$

Water-Cement ratio $=0.45$

Ratio of concrete mix:1 : 1.4 : 2.84 


\section{International Journal of Science and Research (IJSR) \\ ISSN (Online): 2319-7064}

Index Copernicus Value (2013): 6.14 | Impact Factor (2015): 6.391

Table 1: Quantity required for $1 \mathrm{~m}^{3}$ with $10 \%$ wastage 3-cubes for each ratio @ 7 days and 28 days

\begin{tabular}{|c|c|c|c|c|}
\hline Description Of Item & \multicolumn{4}{|c|}{ MIX PROPORTIONS M25 GRADE } \\
\cline { 2 - 5 } & $\begin{array}{c}\text { Conventional } \\
\text { concrete }\end{array}$ & $\begin{array}{c}6 \% \\
\text { Replacement }\end{array}$ & $\begin{array}{c}12 \% \\
\text { Replacement }\end{array}$ & $\begin{array}{c}18 \% \\
\text { Replacement }\end{array}$ \\
\hline Cement $(\mathrm{kg})$ & 415 & 390.1 & 365.2 & 340.3 \\
\hline Fine Aggregate $(\mathrm{kg})$ & 584 & 584 & 584 & 584 \\
\hline Coarse Aggregate $(\mathrm{kg})$ & 1180 & 1180 & 1180 & 1180 \\
\hline Saw dust ash $(\mathrm{kg})$ & - & 24.9 & 49.8 & 74.7 \\
\hline Water (lit) & 186 & 186 & 186 & 186 \\
\hline
\end{tabular}

Mix Proportion for $150 \mathrm{~mm}^{3}$ :

Ratio = 1: $1.4: 2.84=5.24$

For one mould average weight $=9 \mathrm{~kg}$

Quantities Required for one mould

Cement $=\frac{1}{5.24} * 9=1.71 \mathrm{~kg}$

Fine Aggregate $=\frac{1.4}{5.24} * 9=2.40 \mathrm{~kg}$

Coarse Aggregate $=\frac{2.84}{5.24} * 9=4.87 \mathrm{~kg}$

Water $=0.45 * 1.71=0.8$ lit

Mix Proportion for $150 \mathrm{~mm}^{3}$ with $6 \%$ replacement of SDA:

Quantities Required for one mould

SDA $6 \%$ of Cement $=6 \%$ of $1.71=0.11 \mathrm{~kg}$

Cement $=1.6 \mathrm{~kg}$

Fine Aggregate $=\frac{1.4}{5.24} * 9=2.40 \mathrm{~kg}$

Coarse Aggregate $=\frac{2.84}{5.24} * 9=4.87 \mathrm{~kg}$

Water $=0.45 * 1.71=0.8 \mathrm{lit}$

Mix Proportion for $150 \mathrm{~mm}^{3}$ with $12 \%$ replacement of SDA:

Quantities Required for one mould

SDA $12 \%$ of Cement $=12 \%$ of $1.71=0.21 \mathrm{~kg}$

Cement $=1.5 \mathrm{~kg}$

Fine Aggregate $=\frac{1.4}{5.24} * 9=2.40 \mathrm{~kg}$

Coarse Aggregate $=\frac{2.84}{5.24} * 9=4.87 \mathrm{~kg}$

Water $=0.45 * 1.71=0.8$ lit
SDA $18 \%$ of Cement $=18 \%$ of $1.71=0.308 \mathrm{~kg}$

Cement $=1.402 \mathrm{~kg}$

Fine Aggregate $=\frac{1.4}{5.24} * 9=2.40 \mathrm{~kg}$

Coarse Aggregate $=\frac{2.84}{5.24} * 9=4.87 \mathrm{~kg}$

Water $=0.45 * 1.71=0.8 \mathrm{lit}$

Table: Mix Proportion for $150 \mathrm{~mm}^{3}$ :

\begin{tabular}{|c|c|c|c|c|c|c|}
\hline S.no & $\begin{array}{c}\text { SDA-\% } \\
\text { of cement }\end{array}$ & $\begin{array}{c}\text { Cement } \\
\text { Kgs }\end{array}$ & $\begin{array}{c}\text { SDA } \\
\text { Kgs }\end{array}$ & $\begin{array}{c}\text { Fine } \\
\text { aggregate } \\
\text { Kgs }\end{array}$ & $\begin{array}{c}\text { Coarse } \\
\text { aggregate } \\
\text { Kgs }\end{array}$ & $\begin{array}{c}\text { Water } \\
\text { Lit }\end{array}$ \\
\hline Mix-1 & - & 1.71 & - & 2.40 & 4.87 & 0.8 \\
\hline Mix-2 & 6 & 1.60 & 0.11 & 2.40 & 4.87 & 0.8 \\
\hline Mix-3 & 12 & 1.50 & 0.21 & 2.40 & 4.87 & 0.8 \\
\hline Mix-4 & 18 & 1.402 & 0.308 & 2.40 & 4.87 & 0.8 \\
\hline
\end{tabular}

\section{Results and Discussion}

Table 2: Compressive Strength of Conventional and SDA Replaced Concrete Cubes of M25 Grade

Concrete Grade: M25 Cubes: 3 NOS SDA-6\%

\begin{tabular}{|c|c|c|c|}
\hline \multirow{2}{*}{$\begin{array}{c}\text { Grade of } \\
\text { Concrete }\end{array}$} & \multirow{2}{*}{$\begin{array}{c}\text { Type of } \\
\text { Concrete }\end{array}$} & 7 DAYS & 28 DAYS \\
\cline { 3 - 4 } & Strength In Days (N/mm & \\
\hline \multirow{2}{*}{ M25 } & Conventional & 35.68 & 40.44 \\
\cline { 2 - 4 } & SDA Concrete & 31.11 & 36.44 \\
\hline
\end{tabular}

Type of Concrete

Mix Proportion for $150 \mathrm{~mm}^{3}$ with $18 \%$ replacement of SDA:

Quantities Required for one mould

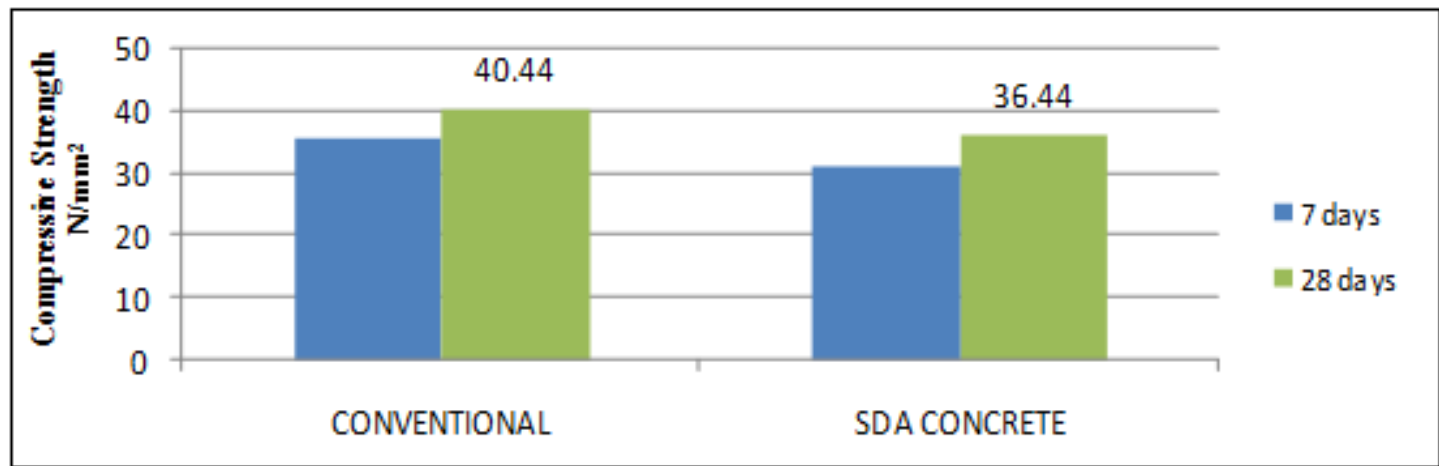

Chart 2: Graph between Conventional and 6\% SDA Replaced

Volume 5 Issue 6, June 2016 www.ijsr.net

Licensed Under Creative Commons Attribution CC BY 


\section{International Journal of Science and Research (IJSR) \\ ISSN (Online): 2319-7064}

Index Copernicus Value (2013): 6.14 | Impact Factor (2015): 6.391

Table 15: Compressive Strength of Conventional and SDA Replaced Concrete Cubes of M25 Grade.

Concrete Grade: M25 Cubes: 3 NOS SDA-12\%

\begin{tabular}{|c|c|c|c|}
\hline \multirow{2}{*}{$\begin{array}{c}\text { Grade of } \\
\text { Concrete }\end{array}$} & \multirow{2}{*}{$\begin{array}{c}\text { Type of } \\
\text { Concrete }\end{array}$} & \multicolumn{2}{|c|}{ Strength In Days (N/mm } \\
\cline { 3 - 4 } & & 7 DAYS & 28 DAYS \\
\hline \multirow{2}{*}{ M25 } & Conventional & 35.68 & 40.44 \\
\cline { 2 - 4 } & SDA Concrete & 22.88 & 31.55 \\
\hline
\end{tabular}

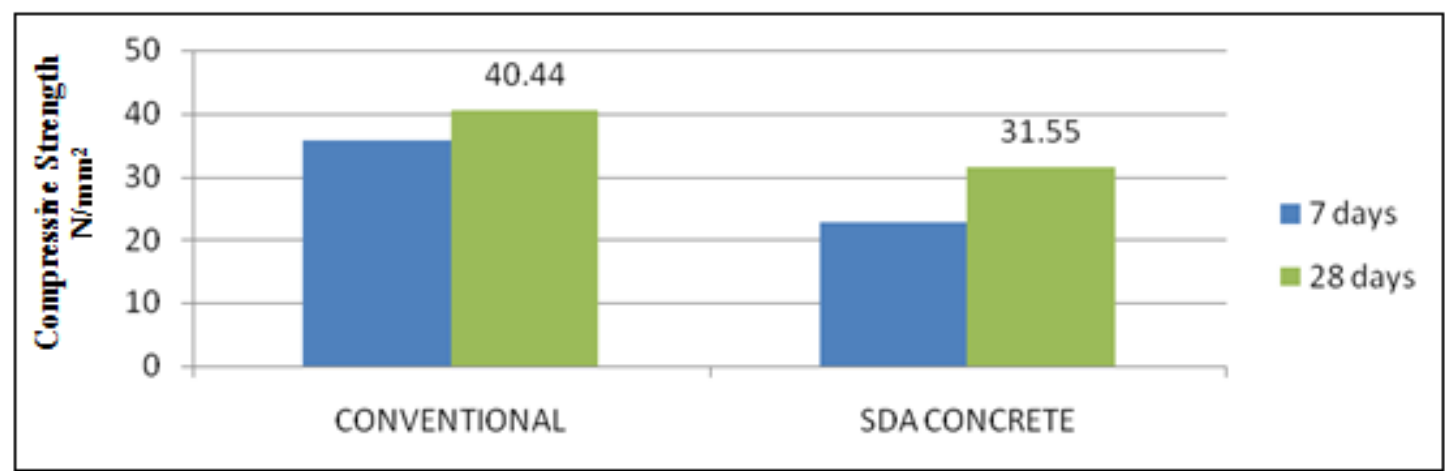

Chart 3: Graph between Conventional and 12\% SDA Replaced

\section{Type of Concrete}

Table 16: Compressive Strength Of Conventional And Sda Replaced Concrete Cubes Of M25 Grade. Concrete Grade: M25 Cubes: 3 NOS SDA-18\%

\begin{tabular}{|c|c|c|c|}
\hline \multirow{2}{*}{$\begin{array}{c}\text { Grade of } \\
\text { Concrete }\end{array}$} & $\begin{array}{c}\text { Type of } \\
\text { Concrete }\end{array}$ & 7 DAYS & 28 DAYS \\
\cline { 3 - 4 } & & Strength in Days $\left(\mathrm{N} / \mathrm{mm}^{2}\right.$ \\
\hline \multirow{2}{*}{ M25 } & Conventional & 35.68 & 40.44 \\
\cline { 2 - 4 } & Sda Concrete & 16.88 & 25.11 \\
\hline
\end{tabular}

\section{Type of Concrete}

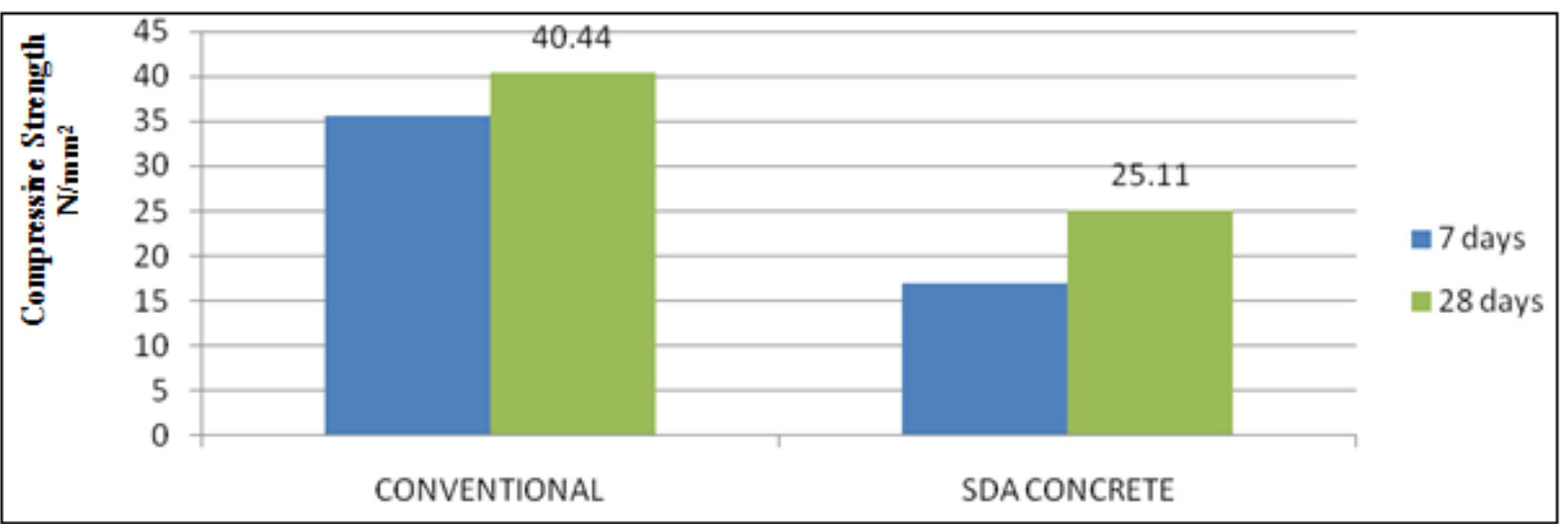

Chart 4: Graph between Conventional and 18\% SDA Replaced

Table 17: Compressive strengths of hardened concrete

\begin{tabular}{|c|c|c|c|c|}
\hline & $\begin{array}{c}\text { Conventional } \\
\text { Concrete }\end{array}$ & $\begin{array}{c}6 \% \\
\text { Replacement }\end{array}$ & $\begin{array}{c}12 \% \\
\text { Replacement }\end{array}$ & $\begin{array}{c}18 \% \\
\text { Replacement }\end{array}$ \\
\hline 0 Day compressive strength $\left(\mathrm{N} / \mathrm{mm}^{2}\right)$ & 0 & 0 & 0 & 0 \\
\hline 7 Day compressive strength $\left(\mathrm{N} / \mathrm{mm}^{2}\right)$ & 35.68 & 31.11 & 22.88 & 16.88 \\
\hline 28 Day compressive strength $\left(\mathrm{N} / \mathrm{mm}^{2}\right)$ & 40.44 & 36.44 & 31.55 & 25.11 \\
\hline
\end{tabular}

\section{Volume 5 Issue 6, June 2016} www.ijsr.net 
International Journal of Science and Research (IJSR)

ISSN (Online): 2319-7064

Index Copernicus Value (2013): 6.14 | Impact Factor (2015): 6.391

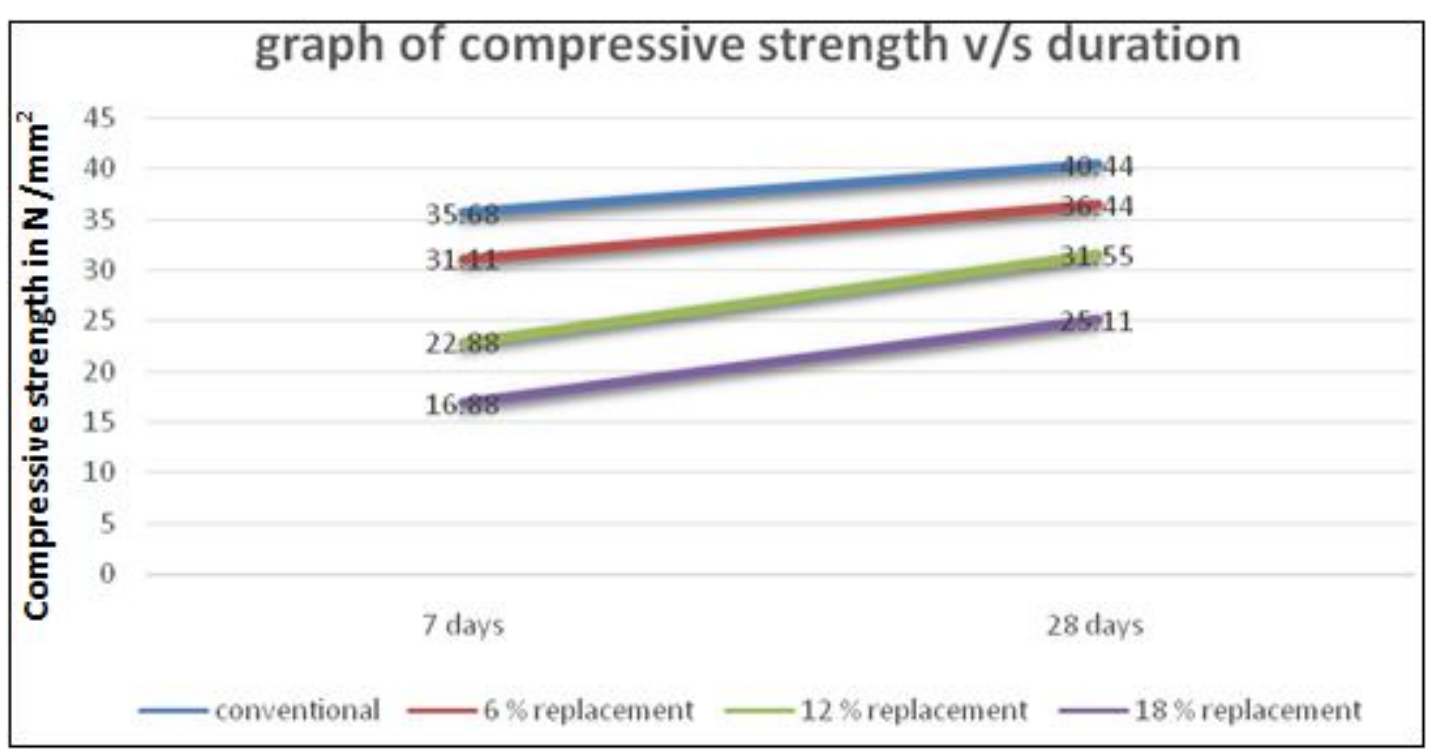

Chart 5: Graph of Compressive Strength Development

\section{Recommendations}

Based on the results, discussions and conclusions, the following recommendations arise:

1) A compromise between the strength of concrete, cost savings of cement replacement and reduction of carbon emission would allow a replacement of up to $12 \%$ for normal strength concrete. The normal strength concrete may be put to uses such as the construction of structural members in buildings. Any cement replacement above $12 \%$ would be cheaper and friendlier to the environment but would produce low strength concrete. This may be used in works such as paving and minor repairs.

2) Further research should be done on the microstructure of SDAC. This would help find ways of improving the SDAC so that higher percentages of replacement would still result to normal strength concrete that would be usable for normal structural works such as construction of buildings.

3) A further study on the effect of different combustion temperatures and methods of combustion on the mineral content of the saw dust ash to find out the optimum temperature and method of combustion to yield ash with a good content of Calcium which will blend well with the ordinary Portland cement. Also, further research should be done on a method of combustion that would be friendlier to the environment.

\section{Conclusion}

The objectives of the research were met by means of the methods outlined in Chapter Three. SDAC, up to a cement replacement of $12 \%$ by weight, can be used for applications requiring moderate strength concrete as it exhibited adequate compressive strength. The splitting tensile strength and the flexural strength of the SDAC also decreased with more replacement of the cement.. The workability of the SDAC however decreased as greater proportions of cement were replaced by the saw dust ash. Therefore, more water would be required to improve on the workability of the concrete having greater proportions of saw dust ash as cement replacement.
The saw dust ash exhibited cementitious properties as shown by its ability to blend well with ordinary Portland cement. It also has a lower specific gravity value than normal Portland cement implying that it would make the resultant concrete lighter with more proportions of cement replaced. The ash also had a content of calcium oxide that would compare well with that of OPC though lower. The temperature and method used in burning the saw dust would also have an impact on the properties of the resultant ash. Controlled burning would be the most suitable method as it would ensure complete combustion of the saw dust into ash.

The cost of the SDAC was found to be lower than the cost of the PCC. This is because saw dust concrete utilizes a waste product (saw dust) and converts it into economic and sustainable use. Therefore, the replacement of cement with saw dust ash would be beneficial to low income areas which may not afford to keep up with the rising costs of cement.

The reduction in carbon emissions was found to be positively correlated with the proportion of cement replaced. Therefore, the more the proportion of cement replaced, the more would be the reduction in carbon emissions.

\section{References}

[1] Alok, J. (2008, December 31). Revealed: The Cement that Eats Carbon Dioxide. The Guardian.

[2] Chaid , R., Jauberthie, R., \& Randell , F. (2004). Influence of a Natural Pozzolan on High Performance Mortar. Indian Concrete Journal, 22.

[3] Davidson, J. (2013, January). India's 1.2 million tpa cement plant on track for 2014 completion.

[4] World Cement.

[5] Halstead, W. (1986). Use of Fly Ash in Concrete. National Cooperative Highway Research Project.

[6] Hewlett, P. (2012). Lea's Chemistry of Cement and Concrete. Elsevier.

[7] Hume. (2006). Wood Ashes: How to use them in the Garden .

[8] Imperial Innovations. (2011, January 26). Imperial Innovations. Retrieved from Imperail 


\section{International Journal of Science and Research (IJSR) \\ ISSN (Online): 2319-7064}

Index Copernicus Value (2013): 6.14 | Impact Factor (2015): 6.391

Innovations:http://www.imperialinnovations.co.uk/news centre/news/imperialinnovations-portfolio-companynovacem-rai/

[9] International Energy Agency. (2014). Cement Roadmap. Retrieved from International Energy Agency:http://www.iea.org/publications/freepublication s/publication/Cement_Roadmap_Foldout_WEB.pdf

[10] India Ministry of Environment and Natural Resources. (1999). Environmental Management and Co-ordination Act. Government of the Republic of India.

[11] India Ministry of Planning and National Development, NESC. (2007). India: Vision 2030. Government of the Republic of India.

[12] Mahasenan, Natesan, Smith , S., Humphreys, K., \& Kaya, Y. (2003). The Cement Industry and Global Climate Change: Current and Potential Future Cement Industry CO2 Emissions. Greenhouse Gas Technologies - 6th International Conference (pp. 995-1000). Oxford.

[13] Malhotra, V. (1998). The Role of Supplementary Cementing Materials in Reducing Greenhouse Emissions. Concrete, Fly Ash and the Environment Proceedings. Building Green.

[14] Specification for Coarse and Fine Aggregates from Natural Sources for Concrete. IS: 383-1970, Bureau of Indian Standards, New Delhi. 